\title{
ANALISA NILAI THRUST DAN TORQUE PROPELLER TIPE B-SERIES PADA KAPAL SELAM MIDGET 150M DENGAN VARIASI SKEW ANGLE DAN BLADE AREA RATIO (AE/AO) MENGGUNAKAN METODE CFD
}

\author{
Putra Bangkit SetyaBudi ${ }^{1)}$, Deddy Chrismianto ${ }^{1)}$, Good Rindo, ${ }^{1)}$ \\ ${ }^{1)}$ Program Studi S1 Teknik Perkapalan, Fakultas Teknik, Universitas Diponegoro \\ Email : sb.putrabangkit@gmail.com, deddychrismianto@yahoo.co.id,good.rindo@gmail.com
}

\begin{abstract}
Abstrak
Kapal selam merupakan kapal yang mampu beroperasi dibawah air dengan mandiri, namun juga harus bergerak senyap dibawah air tanpa terdeteksi. Maka dari itu salah satu kebutuhan paling penting dalam kapal selam adalah Baling-Baling atau Propeller. Baling-baling kapal selam membutuhkan beberapa kriteria khusus yaitu baling-baling kapal yang dapat memberikan gaya dorong yang besar dengan tingkat kebisingan yang rendah. Maka desain propeller harus memiliki nilai thrust yang besar, nilai tekanan yang rendah, dan aliran baling-baling yang halus. Penelitian ini menganalisa baling-baling kapal selam jenis $B$ 7 Series dengan variasi Skew Angle $\left(27.7^{0}, 29.7^{0}\right.$ dan $\left.31.7^{0}\right)$ dan Blade Area Ratio (0.55, 0.59 dan 0.70) dengan penambahan Kort Nozzle C Tipe Shushkin Nozzle serta dengan tiga nilai RPM yaitu, 400 RPM, 450 RPM dan 500 RPM, sehingga didapatkan jenis baling - baling yang optimum untuk kapal selam midget type $150 \mathrm{~m}$ dengan menggunakan program Computational Fluid Dynamics (CFD). Dalam proses analisa menggunakan software berbasis CFD, kami mendapatkan hasil dari semua model baling - baling yaitu bentuk aliran, nilai thrust dan nilai pressure yang berbeda sesuai dengan RPM yang diberikan. Dari kesembilan variasi model yang telah dibandingkan didapat model baling - baling yang optimum yaitu B 7 Series pada Model $2\left(27,7^{0} \&\right.$ 0,59) putaran 400 RPM dengan nilai rata-rata tekanan 66,34 Pa, dan aliran turbulen dengan kecepatan rata - rata $15,56 \mathrm{~m} / \mathrm{s}$.

Kata kunci : Kapal Selam, Propeller, Skew Angle, Blade Area Ratio (Ae/Ao), Kort Nozzle, dan CFD
\end{abstract}

\section{PENDAHULUAN}

Kapal selam merupakan kapal yang mampu beroperasi dibawah air dengan mandiri. ${ }^{[2]}$ Selain itu, Kriteria khusus yang harus dimiliki oleh sebuah kapal selam yaitu kemampuan bermanuver dibawah air, kemampuan untuk memata-matai dan menyerang dari dasar laut tanpa bisa terdeteksi terlebih dahulu ${ }^{[10]}$..

Sebuah kapal selam didesain untuk tidak lambat dalam pergerakannya dibawah air, namun juga harus bergerak senyap dibawah air tanpa terdeteksi. Untuk dapat bergerak senyap dibawah air, kebutuhan yang paling penting bagi balingbaling kapal selam yaitu rendahnya kebisingan

KAPAL, Vol. 13, No. 3 Oktober 2016 yang ditimbulkan oleh baling-baling/propeller tersebut.

Propeller sendiri merupakan salah satu alat gerak kapal mekanik yang memberian kekuatan dengan mengubah rotasi gerak ke gaya dorong, propeller terdiri dari bebrapa blade dan propeller beroperasi seperti perputaran pada skrup. ${ }^{[14]}$ Dalam Perkembangannya propeller/baling-baling mengalami beberapa modifikasi bentuk dengan tujuan mendapatkan efisiensi yang paling baik sebaga alat penggerak kapal, salah satu modifikasi itu yaitu skew angle dan blade area ratio (Ae/Ao).

Kemudian penambahan atau penggunaan Kort Nozzle Propeller terbukti dapat meningkatkan gaya dorong/Thrust. Fenomena yang terjadi pada propeller yang diselubungi 
tabung (Kort Nozzle) adalah kecepatan aliran air yang berada di dalam tabung lebih cepat dibandingkan aliran air yang berada diluar tabung yang mengakibatkan tekanan didalam tabung lebih kecil dari pada diluar tabung. ${ }^{[16]}$

Dengan memperhatikan pokok permasalahan yang terdapat pada latar bealakang, maka dapat diambil beberapa rumusan masalah sebagai berikut.

1. Bagaimanakah perbandingan dari hasil variasi skew angle,blade area ratio serta penambahan Kort Nozzle C Tipe Shushkin Nozzle terhadap pressure dan Streamline velocity pada propeller kapal selam tipe $B$-Series ?

2. Berapakah sudut skew anlge dan blade area ratio yang optimum dengan penambahan Kort Nozzle C Tipe Shushkin Nozzle untuk propeller kapal selam tipe $B$-Series dengan variasi yang ada ?

Batasan masalah digunakan sebagai arahan serta acuan dalam penulisan penelitian sehingga sesuai dengan permasalahan serta tujuan yang diharapkan. Adapun batasan permasalahan yang dibahas dalam penelitian ini adalah:

1. Propeller yang digunakan adalah

$\begin{array}{ll}\text { Diameter } & : 1.00[\mathrm{~m}] \\ \text { Skew Angle } & : 29.7^{\circ} \\ \text { Pitch } & : 1.09 \\ \text { Blade Rasio } & : 0.59 \\ \text { No. Of Blade } & : 7 \\ \text { Type } & : \text { B-Series }\end{array}$

2. Data propeller diambil dari spek propeller yang terdapat di dalam jurnal mendekati kesamaan dimensi dari propeller tersebut.

3. Variasi sudut kemiringan skew angle adalah $27.7^{0}, 29.7^{0}$ dan $31.7^{0}$

4. Variasi Blade Area Rasio (Ae/Ao) adalah 0.55 , 0.59 dan 0,7

5. Jenis Kort Nozzle yang digunakan Kort Nozzle C Tipe Shushkin Nozzle

6. Hanya membandingkan desain yang ada.

7. Asumsi aliran di depan propeller adalah steady-uniform

8. Analisa pada keadaan open water.
9. Thruster dianalisa pada kondisi keadaan statis sesuai dengan putaran yang diinginkan.

10. Hanya menganalisa distribusi aliran fluida dibelakang thruster.

11. Mengabaikan faktor maupun kondisi aliran air (fluida) dari badan propeller.

12. Tidak memperhitungkan analisa biaya.

13. Menggunakan software analisa CFD yaitu Ansys CFX.

14. Boss Cap menggunakan bentuk setengah lingkaran

15. Kemiringan pada Boss yaitu 5 derajat dari belakang propeller hingga boss cap Boss Cap berbentuk setengah lingkaran.

16. Tidak melakukan variasi bentuk Boss atau $\mathrm{Hub}$

Berdasarkan latar belakang di atas maka tujuan dari penelitian ini adalah:

1. Untuk mengetahui perbandingan dari hasil variasi skew angle,blade area ratio serta penambahan Kort Nozzle C Tipe Shushkin Nozzle terhadap pressure dan Streamline velocity pada propeller kapal selam tipe $B$ Series.

2. Untuk mendapatkan sudut skew anlge dan blade area ratio yang optimum dengan penambahan Kort Nozzle C Tipe Shushkin Nozzle untuk propeller kapal selam tipe $B$ Series dengan variasi yang ada

\section{TINJAUAN PUSTAKA}

\subsection{Propeller Kapal Selam}

Kebutuhan yang paling penting untuk propeller kapal selam adalah rendahnya tingkat kebisingan yang ditimbulkan. Oleh karena itu, ditakutkan adanya kavitasi yang menimbulkan kebisingan. Kebisingan disini diakibatkan oleh gelembunggelembung air yang mendidih.

Parameter yang biasanya dapat bervariasi selama proses desain adalah diameter, jumlah blade, sudut rake, distribusi sirkulasi (pitch dan chamber) dan geometri trailing edge. Untuk kapal selam biasanya ada sedikit pembatasan diameter 
daripada kapal permukaan yang normal dan ketika meningkatkan diameter berarti penurunan spesifik gaya dorong propeller dan kecepatan aliran rata-rata yang lebih tinggi. ${ }^{[7]}$

Beberapa hal yang dibutuhkan oleh oleh system propulsi dan juga propeller, yaitu ${ }^{[8]}$ :

$>$ Manuver tinggi muncul dan khususmya dalam kondisi menyelam.

Peningkatan perlindungan dengan mengurangi emisi kebisingan dan dalam melawan hambatan.

Baling-baling bebas dari kavitasi dengan memadai margin.

$>$ Propeller dengan efisiensi tinggi.

\subsection{Karakteristik Baling-baling Kapal}

Setiap tipe dari masing-masing baling-baling kapal memiliki karakteristik kurva kinerja yang berbeda-beda. Sehingga kajian terhadap karakteristik baling-baling kapal tidak dapat di-generalisasi untuk keseluruhan bentuk atau tipe dari balingbaling. Persamaan sebagai berikut :

$\mathrm{J}=\frac{V a}{n x D}$

Dimana:

KT = Koefisien gaya dorong balingBaling

$\mathrm{KQ}=$ Koefisien torsi baling-baling

$\mathrm{J}=$ Koefisien advanced baling- baling

$\mathrm{Va}=$ kecepatan advanced

$\mathrm{D}=$ diameter propeller

$\mathrm{n} \quad=$ putaran propeller

$\mathrm{T}=$ thrust propeller

$\mathrm{Q}=$ torque propeller

$\rho \quad$ = massa jenis fluida (fluid density

\subsection{Skew Angle Propeller}

Skew Angle Propeller adalah pengertian yaitu sudut antara propeller shaft center line sampai dengan blade tip. Blade tip sendiri adalah pertemuan dari trailing edge dan leading edge pada surface propeller dan merupakan jarak maksimum dari radius propeller. Skew Angle dapat berfungsi untuk mengurangi beban dan tekanan propeller saat memeacah aliran fluida. ${ }^{[2]}$

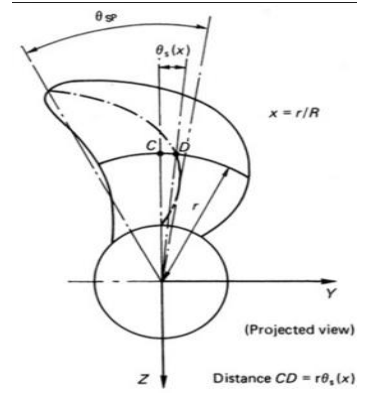

Gambar. 1 Skew Angle Propeller

\subsection{Blade Area Ratio (Ae/Ao)}

Blade Area Rasio atau BAR adalah perbandingan antara luasan daun baling baling dengan luas perputaran penuh blade tip atau biasa disebut dengan $=A_{0}$. Balam kenyataannya $\operatorname{ada}^{2} \cdot$ B $^{4}$ type BAŖ̧.nýatú : Projected Area, Developed Area, dan Expanded area

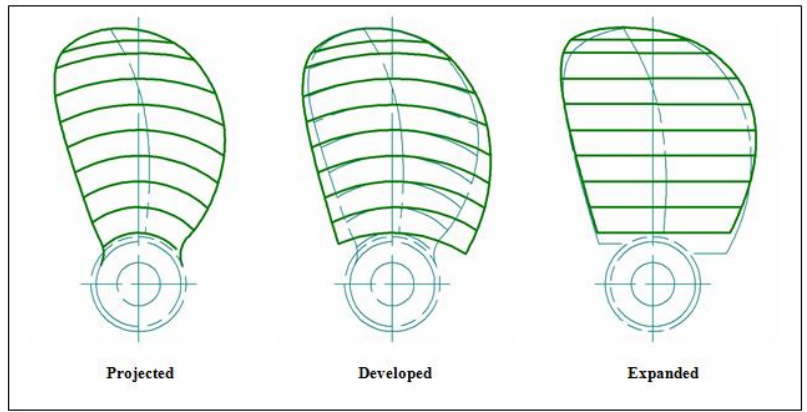

Gambar. 2 Blade Area Ratio (Ae/Ao)

\subsection{Kort Nozzle Propeller}

Kort nozzle Propeller merupakan Propeller yang memiliki saluran (duct) berupa foil yang mengelilingi balingbaling sehingga membentuk selubung atau tabung (nozzle). Unit ini juga disebut sebagai tabung Kort. Kort diambil dari nama Ludwig Kort, yaitu perancang balingbaling tabung (ducted propeller) untuk kapal yang pertama; pada tahun $1927 .^{[15]}$

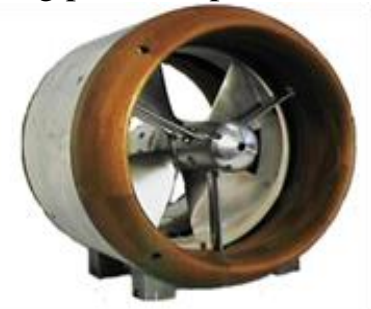

Gambar. 3 Kort nozzle Propeller 
digambarkan dalam flowchart berikut:

\subsection{Teori Baling - Baling}

Dalam Teori baling-baling ${ }^{[6]}$, dijelaskan bahwa pada awalnya teori balingbaling dijelaskan dengan cara yang sangat sederhana, yaitu berdasarkan prinsip kerja mur dan baut (screw \& nut).

2.7.1. Teori Momentun Baling - Baling

Gaya dorong yang dihasilkan oleh bekerjanya baling-baling adalah disebabkan oleh adanya perbedaan momentum yang terjadi pada waktu daun baling-baling bergerak difluida.

Adanya arus air karena berputarnya baling-baling di air, maka akan timbul gaya reaksi yang merupakan gaya yang dihasilkan oleh daun baling-baling. Gaya tersebut merupakan gaya dorong atau thrust ${ }^{[8]}$.

\subsection{Computational Fluid Dynamics}

Computational Fluid Dynamics $(C F D)^{[12]}$, merupakan salah satu cabang dari mekanika fluida yang menggunakan metode numerik dan algoritma untuk menyelesaikan dan menganalisa permasalahan yang berhubungan dengan aliran fluida. Tujuan CFD untuk memprediksi secara akurat tentang aliran fluida, perpindahan panas dan reaksi kimia yang melibatkan satu atau semua fenomena diatas.

Computational Fluid Dynamics terdiri dari tiga elemen utama yaitu:
a. Pre Processor
b. Solver Manager
c. Post Processor

\section{METODOLOGI PENELITIAN}

\subsection{Diagram Alir}

Metodologi penelitian adalah kerangka dasar dari tahapan penyelesaian penelitian. Metodologi tersebut mencakup semua kegiatan yang akan dilaksanakan untuk memecahkan masalah atau melakukan proses analisa terhadap permasalahan tugas akhir ini. Tahapannya

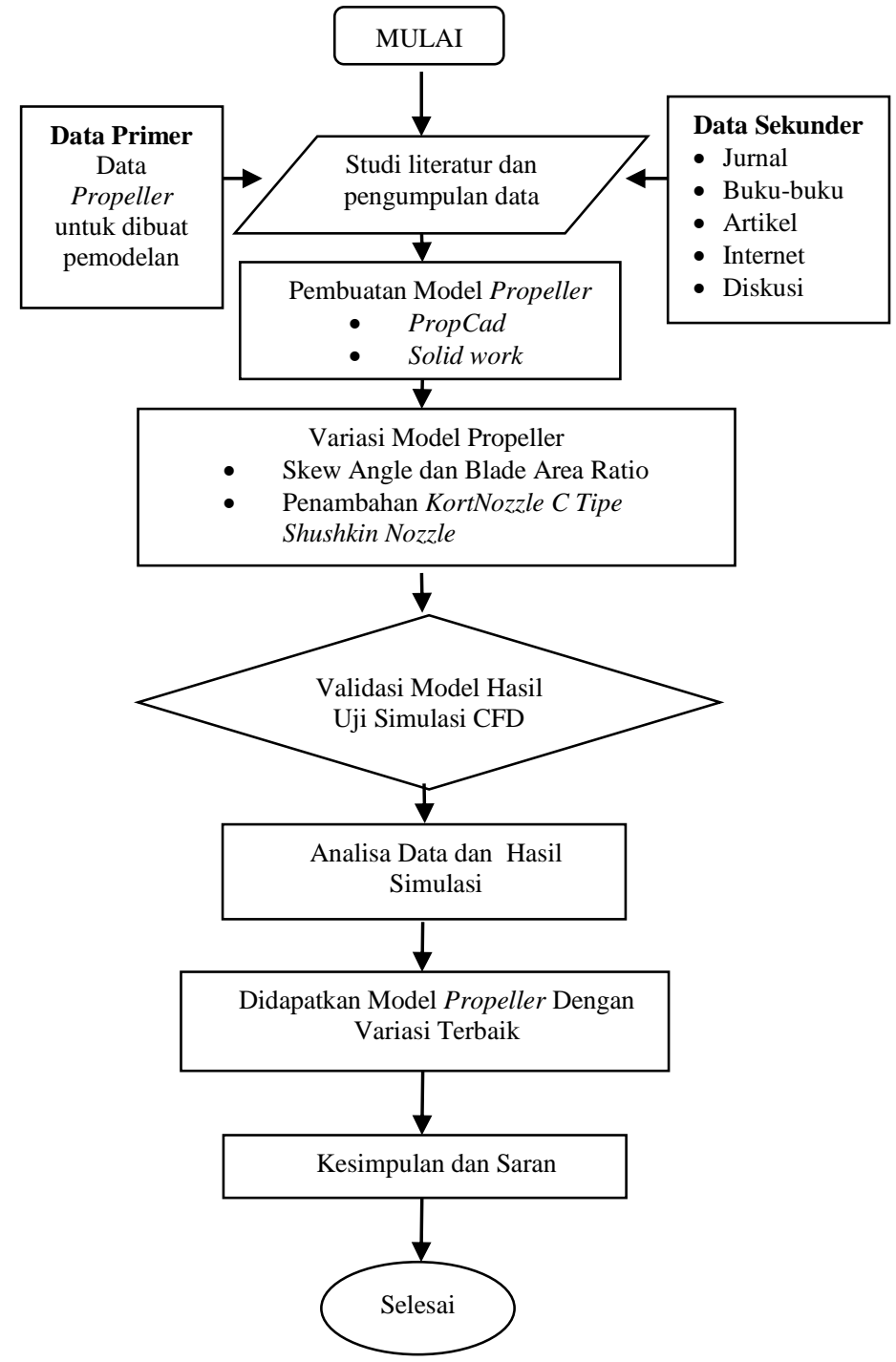

Gambar. 4 Diagram Alir Penelitian

\section{HASIL DAN PEMBAHASAN}

\subsection{Pembuatan Model}

Data ukuran utama propeller diolah menggunakan software PropCad (gambar.2) yang merupakan software pengolah koordinat baling - baling. 


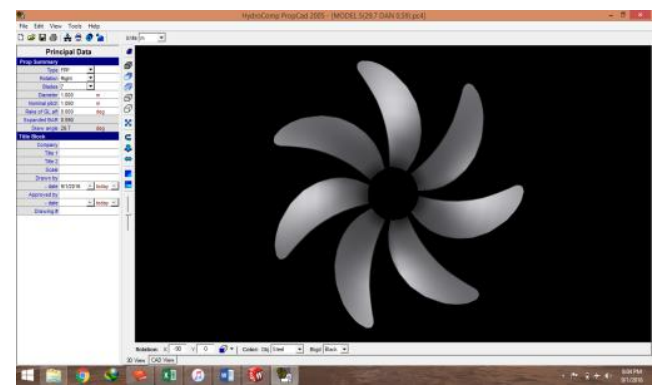

Gambar. 5 Software PropCad

Selanjutnya dilakukan pembuatan 3D model dan melakukan variasi untuk diolah menjadi benda solid sebelum dimasukkan ketahap analisa, pemodelan 3D tersebut menggunakan software solidwork (gambar.3)

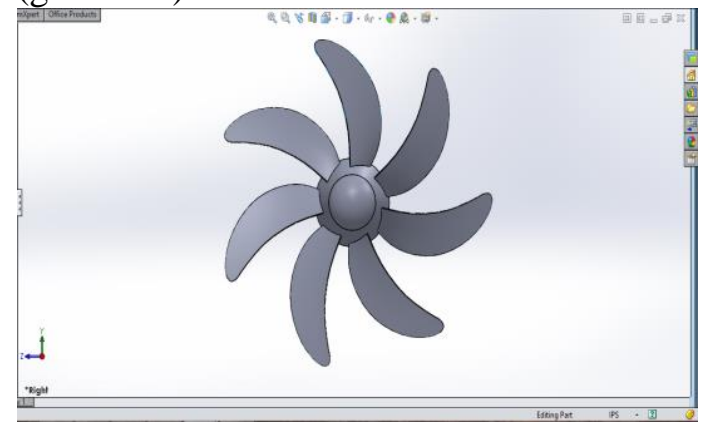

Gambar. 6 Software solidwork

Tahap selanjutnya yaitu geometry dimana model dilakukan pengecekan apakah model sudah solid. Lalu dilakukan pembentuk boundary pada bidang sumbu $\mathrm{x}$ $\mathrm{y} z$ dan pendefinisian setiap bagian boundary seperti pengaturan inlet, outlet, dan wall.

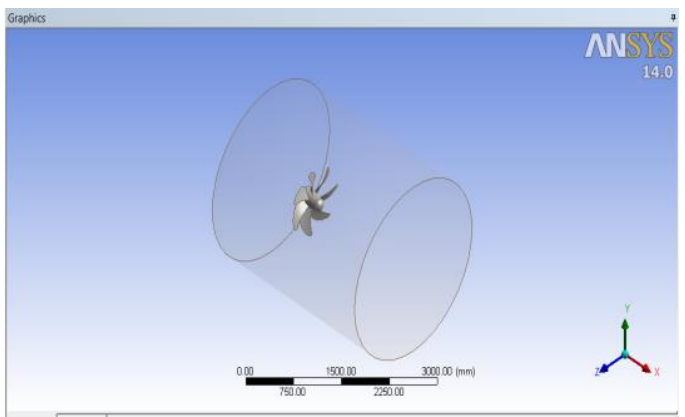

Gambar. 7 Tahap Geometry

Selanjutnya tahap meshing untuk menentukan ukuran tiap elemen dan mengatur kedetailan melalui ukuran elemen yang kita gunakan.

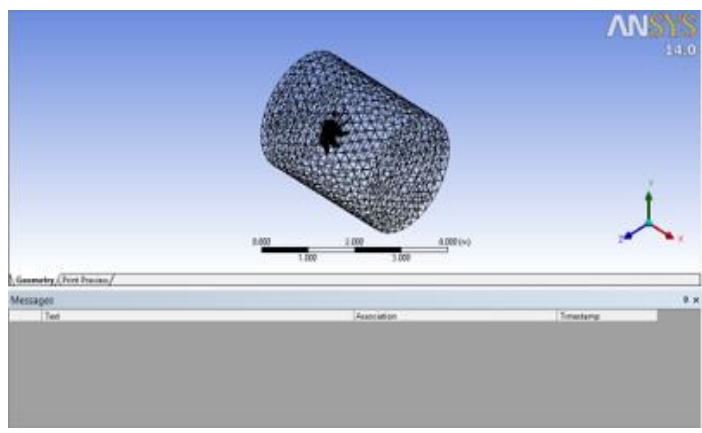

Gambar. 8 Tahap Mesh

Selanjutan kita mengatur setiap kriteria yang kita gunakan dengan mengatur Set-up. Set-up yang digunakan merupakan kriteria yang telah di validasi dahulu sebelumnya sehingga mendapatkan hasil yang memiliki error tidak jauh dari hasil penelitian yang telah dilakukan. Berikut Domain Physics yang digunakan.

Tabel.1 Domain Default

\begin{tabular}{|c|c|}
\hline \multicolumn{2}{|c|}{ Domain - Default Domain } \\
\hline Type & Fluid \\
\hline Location & B619 \\
\hline \multicolumn{2}{|c|}{ Materials } \\
\hline \multicolumn{2}{|l|}{ Water } \\
\hline Fluid Definition & Material Library \\
\hline Morphology & Continuous Fluid \\
\hline \multicolumn{2}{|c|}{ Settings } \\
\hline Buoyancy Model & Non Buoyant \\
\hline Domain Motion & Rotating \\
\hline Angular Velocity & {$\left[\mathrm{rev} \min ^{\wedge}-1\right]$} \\
\hline Axis Definition & Coordinate Axis \\
\hline Rotation Axis & Coord 0.1 \\
\hline Reference Pressure & $1.0000 \mathrm{e}+00[\mathrm{~atm}]$ \\
\hline Heat Transfer Model & Isothermal \\
\hline Fluid Temperature & $2.5000 \mathrm{e}+01[\mathrm{C}]$ \\
\hline Turbulence Model & k epsilon \\
\hline Turbulent Wall Functions & Scalable \\
\hline
\end{tabular}

Berikut merupakan gambar dari pengaturan set-up pada boundary yang telah dibuat pada tahap sebelumnya.

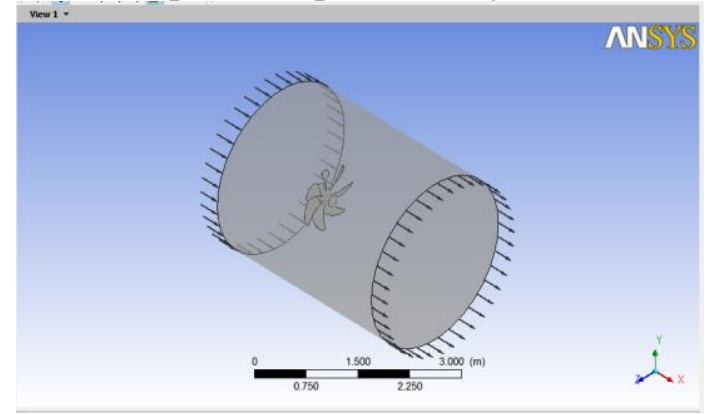


Gambar. 9 Boundary Set-up

Tahap solution yaitu tahap dimana boundary yang telah diberi kriteri dilakukan iterasi hingga didapatkan hasil yang convergence.

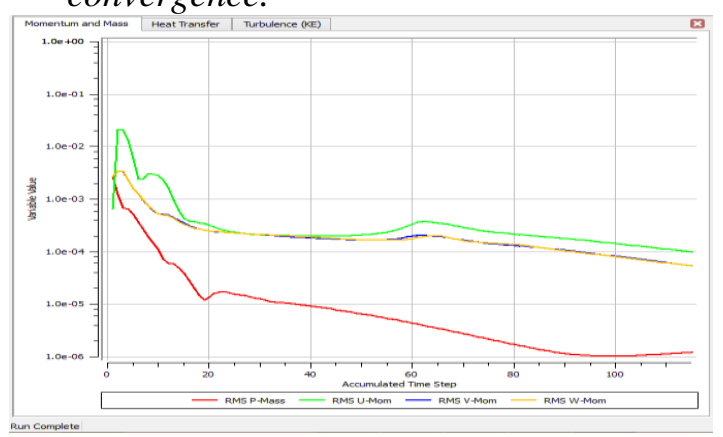

Gambar. 10 Convergence model

Tahap akhir yaitu tahap post dimana kita mendapatkan hasil yang dapat disimulasikan baik 3D ataupun 2D.

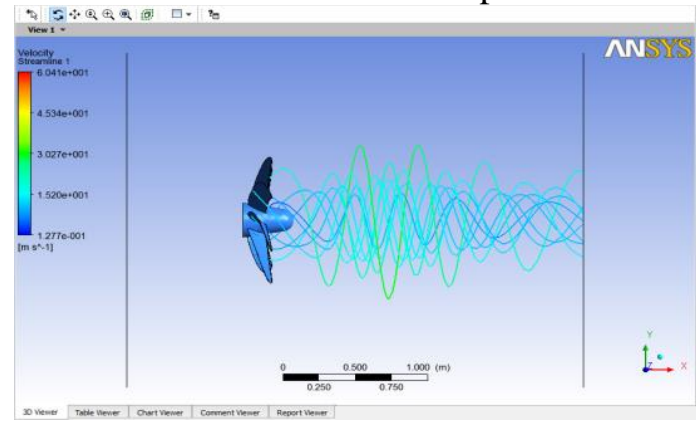

Gambar. 11 Result model

\subsection{Validasi Model}

Validasi digunakan untuk menentukan boundary condition yang tepat untuk menganalisa 4 model propeller. Acuan model untuk divalidasi diambil dari pengujian propeller kapal selam ${ }^{[6]}$, yaitu propeller yang digunakan tipe $B-8$ series, berikut data propeller untuk di validasi :

- Diameter propeller : $1,00 \mathrm{~m}$

- Jumlah blade : 7

- Pitch/diameter : :1,09

- Skew, Degree : : $29,7^{\circ}$

Pada penelitian tersebut diambil rpm yang mendekati rpm yang digunakan pada jurnal. Pada hasil perhitungan dengan CFD pada software berbasis CFD adalah sebagai berikut :
Tabel. 2 Perbandingan Hasil uji coba ${ }^{[5]}$ dengan simulasi CFD

\begin{tabular}{cccc}
\hline $\begin{array}{c}\text { Kecepatan } \\
\text { Rotasi } \\
(\mathrm{rpm})\end{array}$ & $\begin{array}{c}\text { Hasil uji } \\
\text { coba } \\
\text { Coeffisien } \\
\text { Thrust }\left(\mathrm{K}_{\mathrm{T}}\right)\end{array}$ & $\begin{array}{c}\text { Hasil } \\
\text { simulasi } \\
\text { CFD }\left(\mathrm{K}_{\mathrm{T}}\right)\end{array}$ & $\begin{array}{c}\text { Error } \\
(\%)\end{array}$ \\
\hline 450 & 0,098 & 0,096 & $2,04 \%$ \\
\hline
\end{tabular}

\subsection{Pembahasan}

\subsubsection{Pembahasan Perbandingan Pressure pada 400,450 dan 500 Rpm}

Untuk melakukan perbandingan nilai Pressure maka diambil sampel satu garis yang sama pada kesembilan Model yang telah di variasi.

Berikut adalah koordinat dari setiap titik dan garisyang digunakan untuk menentukan pressure pada analisa.

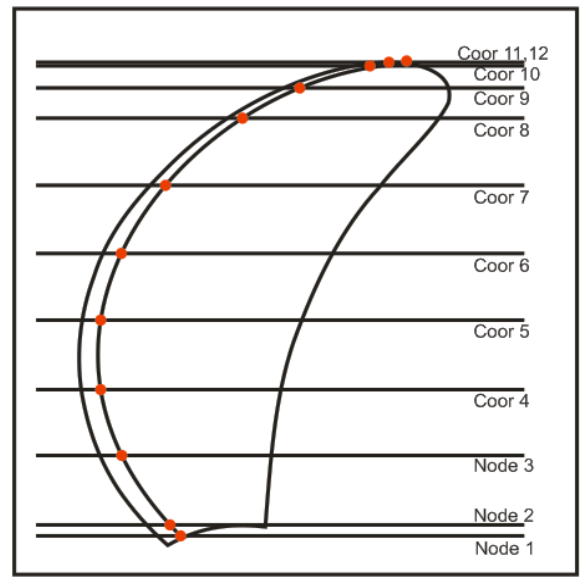

Gambar. 12 Koordinat Pressure

Dari hasil analisa pada $400 \mathrm{rpm}$ propeller B-7 Model $2\left(27,7^{0} \& \quad 0,59\right)$ memiliki pressure terendah senilai 66342,2 $\mathrm{Pa}$, Seperti yang telah terdapat pada tabel 6 berikut :

Tabel. 3 Tabel Pressure Pada 400 RPM

\begin{tabular}{|c|c|c|}
\hline & $\begin{array}{c}\text { Total } \\
(\mathrm{Pa})\end{array}$ & $\begin{array}{c}\text { Rata-Rata } \\
(\mathrm{Pa})\end{array}$ \\
\hline
\end{tabular}




\begin{tabular}{|l|l|l|}
\hline Model 1 & 804698 & 67058.2 \\
\hline Model 2 & 796107 & 66342.2 \\
\hline Model 3 & 798993 & 66582.8 \\
\hline Model 4 & 801817 & 66818.1 \\
\hline Model 5 & 829363 & 69114.0 \\
\hline Model 6 & 814594 & 67882.9 \\
\hline Model 7 & 819338 & 68278.2 \\
\hline Model 8 & 815201 & 67933.4 \\
\hline Model 9 & 838258 & 69854.8 \\
\hline
\end{tabular}

\begin{tabular}{|l|l|l|}
\hline Model 1 & 866989 & 72249.1 \\
\hline Model 2 & 897078 & 74756.5 \\
\hline Model 3 & 869771 & 72480.9 \\
\hline Model 4 & 890337 & 741948 \\
\hline Model 5 & 886882 & 73906.9 \\
\hline Model 6 & 868207 & 72350.6 \\
\hline Model 7 & 915650 & 76304.1 \\
\hline Model 8 & 911910 & 75992.5 \\
\hline Model 9 & 895474 & 74622.8 \\
\hline
\end{tabular}

\section{Rata-Rata PRESSURE (Pa) 400 RPM}

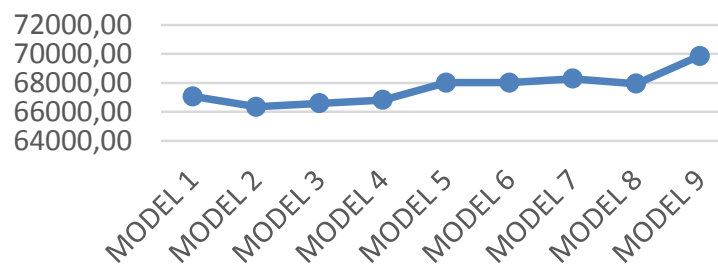

Gambar. 16 Grafik Rata-rata Pressure 400 rpm

Pada simulasi conture didapatkan propeller B-7 Model $2\left(27,7^{0}\right.$ \& $\left.\quad 0,59\right)$ memiliki warna dengan nilai pressure yang rendah.

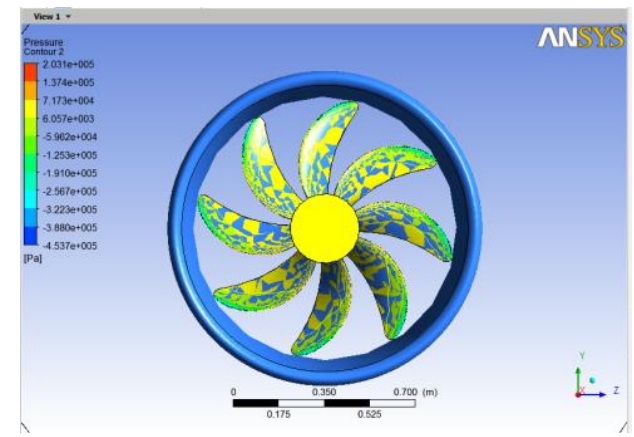

Gambar 4.13 Pressure Contour pada back side 400 RPM Model $2\left(27,7^{0} \& 0,59\right)$

Dari hasil analisa pada $450 \mathrm{rpm}$ propeller B-7 Model $6\left(29,7^{0}\right.$ \& 0,70$)$ memiliki pressure terendah senilai 72350,6 $\mathrm{Pa}$, Seperti yang telah terdapat pada tabel 7 berikut:

Tabel. 4 Tabel Pressure pada 450 RPM

\begin{tabular}{|c|c|c|}
\hline & $\begin{array}{c}\text { Total } \\
(\mathrm{Pa})\end{array}$ & $\begin{array}{c}\text { Rata-Rata } \\
(\mathrm{Pa})\end{array}$ \\
\hline
\end{tabular}

KAPAL, Vol. 13, No. 3 Oktober 2016

\section{Rata-Rata PRESSURE (Pa) 450} RPM

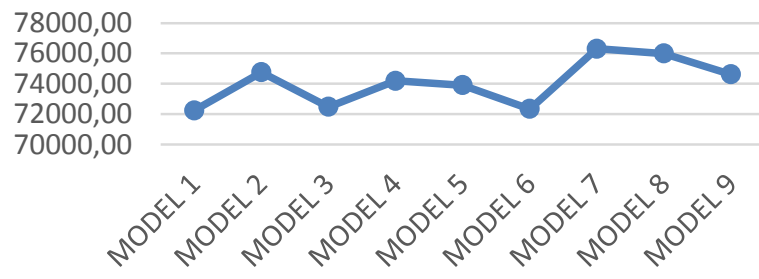

Gambar. 18 Grafik Rata-rata Pressure 450 $\mathrm{rpm}$

Pada simulasi conture didapatkan propeller $B-7$ Model $6 \quad\left(29,7^{0}\right.$ \& $\left.\quad 0,70\right)$ memiliki warna dengan nilai pressure yang rendah.

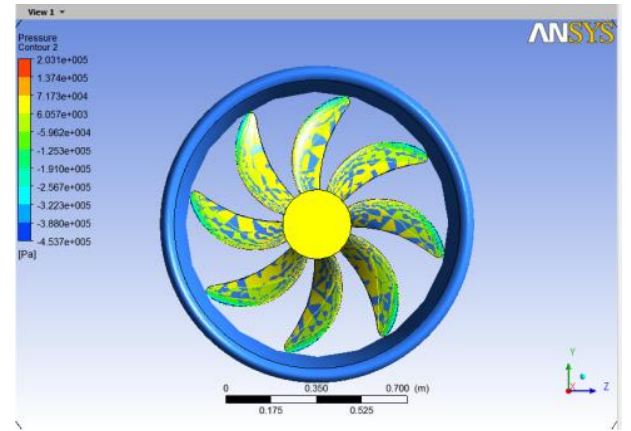

Gambar. 14 Pressure Contour pada back side 450 RPM Model $6\left(29,7^{0} \&\right.$ 0,70)

Dari hasil analisa pada $500 \mathrm{rpm}$ propeller B-7 Model $6 \quad\left(29,7^{0}\right.$ \& 0,70$)$ memiliki pressure terendah senilai 77499,5 $\mathrm{Pa}$, Seperti yang telah terdapat pada tabel 8 berikut:

Tabel. 5 Tabel Pressure pada 500 RPM

\begin{tabular}{|l|c|c|}
\hline & $\begin{array}{c}\text { Total } \\
(\mathrm{Pa})\end{array}$ & $\begin{array}{c}\text { Rata-Rata } \\
(\mathrm{Pa})\end{array}$ \\
\hline Model 1 & 933099 & 77758.2 \\
\hline
\end{tabular}




\begin{tabular}{|l|l|l|}
\hline Model 2 & 956609 & 79717.4 \\
\hline Model 3 & 932767 & 77730.6 \\
\hline Model 4 & 960543 & 80045.3 \\
\hline Model 5 & 952050 & 79337.5 \\
\hline Model 6 & 929993 & 77499.5 \\
\hline Model 7 & 989282 & 82440.2 \\
\hline Model 8 & 985607 & 82133.9 \\
\hline Model 9 & 963360 & 80280 \\
\hline
\end{tabular}

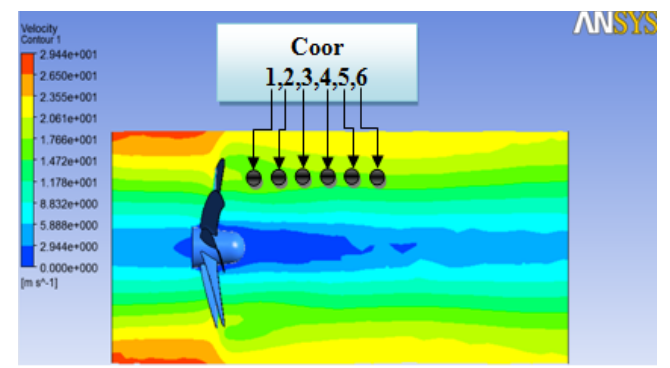

Gambar. 17 Koordinat Velocity

Setelah dibandingkan pada putaran $400 \mathrm{rpm}$ didapatkan bentuk aliran paling baik pada propeller B-7 series Model 5 $\left(29,7^{0} \& 0,59\right)$ dengan nilai kecepatan ratarata $15,65 \mathrm{~m} / \mathrm{s}$, berikut simulasi aliran propeller :

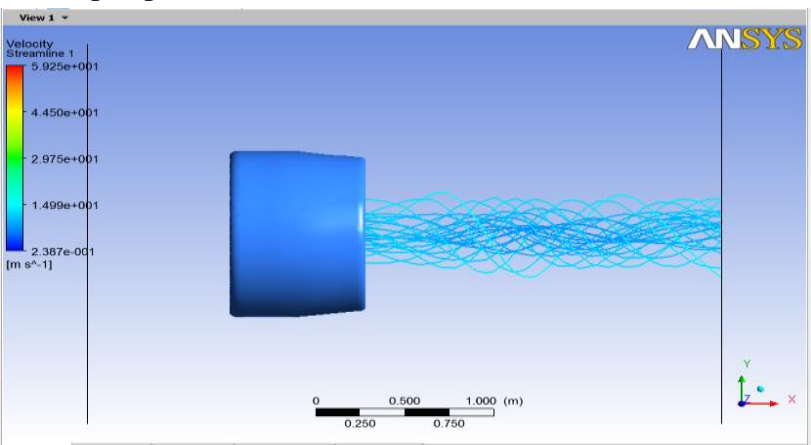

Gambar. 18 Aliran RPM 400 Model 5 (29, $7^{0}$ $\&$ 0.59) with Nozzle Shushkin Type C

Lalu dilakukan pengujian lagi pada putaran $450 \mathrm{rpm}$ namun tetap didapatkan aliran terbaik pada propeller $B-7$ series Model $5 \quad\left(29,7^{0} \& \quad 0,59\right)$ dengan nilai kecepatan rata-rata $17,10 \mathrm{~m} / \mathrm{s}$, berikut simulasi aliran propeller

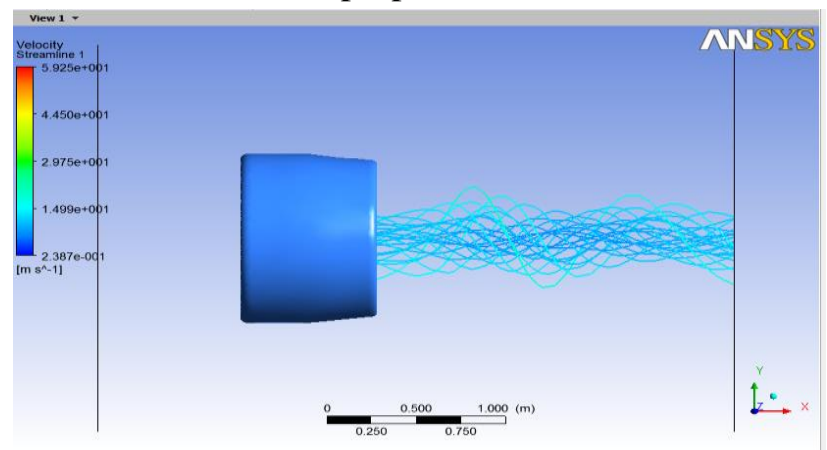

Gambar. 19 Aliran RPM 450 Model 5 (29,7 \& 0.59) with Nozzle Shushkin Type C

Kemudian juga dilakukan pengujian lagi pada putaran $500 \mathrm{rpm}$ namun tetap 
didapatkan aliran terbaik pada propeller $B-7$ series Model $3\left(27,7^{0} \& 0,70\right)$ dengan nilai kecepatan rata-rata $18,33 \mathrm{~m} / \mathrm{s}$, berikut simulasi aliran propeller

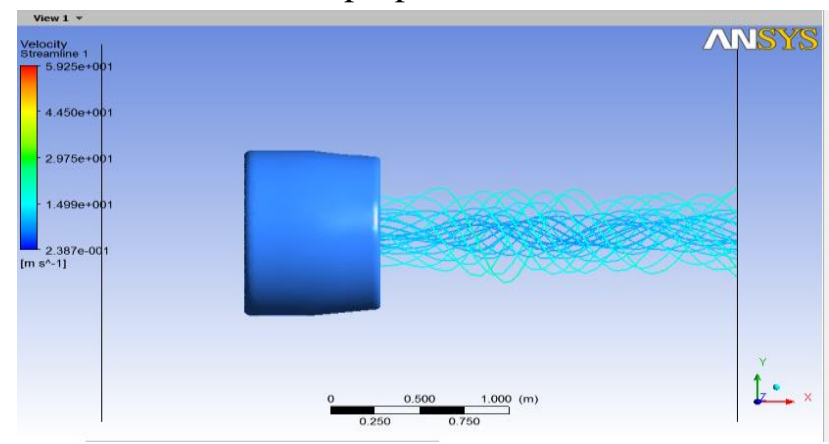

Gambar. 20 Aliran RPM 500 Model 3 (27,7 \& 0.70) with Nozzle Shushkin Type C

Dari penyajian gambar, grafik dan tabel di atas pada tabel 3 sampai dengan tabel 8 dan gambar 12 dan 13 gambar Menunjukan perbandingan sifat propeller sebagai berikut :

1. Nilai rata-rata pressure terendah pada 400 RPM dihasilkan oleh Propeller B-7 Series Model $2\left(27,7^{0} \&\right.$ 0,59) dengan nilai 66342,2 Pa. Sedangkan nilai rata-rata pressure terendah pada 450 RPM dihasilkan oleh Propeller $B-7$ Series Model $6\left(29,7^{0} \&\right.$ 0,70) dengan nilai 72350,6 Pa. Kemudain nilai rata-rata pressure terendah pada 500 RPM dihasilkan oleh Propeller B-7 Series Model $6\left(29,7^{0}\right.$ \& 0,70) dengan nilai 77499,5 Pa.

2. Perbandingan Model Streamline velocity didapatkan hasil bahwa Propeller B-8 Series Model 3 (27, $7^{0}$ $\& 0,70) 500$ RPM memiliki turbulensi terkecil dengan kecepatan rata-rata $18,33 \mathrm{~m} / \mathrm{s}$ dikarenakan memiliki garis turbulensi paling teratur.

\section{KESIMPULAN DAN SARAN}

Berdasarkan percobaan dan simulasi yang telah dilakukan maka dapat disimpulkan sebagai berikut :

1. Setelah mendapatkan hasil dari propeller $B-7$ Series dengan variasi sudut Skew Angle dan Blade Area Ratio (Ae/Ao) yang berjumlah 9 Model, maka dilakukan perbandingan antara putaran 400 RPM,450 RPM dan 500 RPM. Pada RPM 400 didapat hasil untuk nilai pressure terendah senilai $66,34 \mathrm{kPa}$ pada Model $2\left(27,7^{0} \& 0,59\right)$ dan aliran turbulensi terendah yaitu $15,65 \mathrm{~m} / \mathrm{s}$ pada model $5\left(29,7^{0} \& 0,59\right)$. Pada RPM 450 didapat hasil untuk nilai pressure terendah senilai $72,35 \mathrm{kPa}$ pada Model $6\left(29,7^{0} \& 0,70\right)$ dan aliran turbulensi terendah yaitu $17,10 \mathrm{~m} / \mathrm{s}$ pada model 5 $\left(29,7^{0} \&\right.$ 0,59). Pada RPM 500 didapat hasil untuk nilai pressure terendah senilai 77,50 $\mathrm{kPa}$ pada Model $6\left(29,7^{0}\right.$ \& 0,70), dan aliran turbulensi terendah yaitu $18,33 \mathrm{~m} / \mathrm{s}$ pada model $3\left(27,7^{0} \&\right.$ $0,70)$.

2. Dari Perbandingan di atas didapatkan propeller yang optimum untuk digunakan pada kapal selam Midget Type 150m yaitu Propeller B - 7 series yaitu model dengan skew angle $27,7^{0}$ dan blade area ratio 0,59 atau pada Model 2 dengan nilai rata-rata tekanan $66,34 \mathrm{kPa}$, dan aliran turbulen dengan kecepatan rata - rata $15,51 \mathrm{~m} / \mathrm{s}$.

\section{Daftar Pustaka}

[1] Abdilla C,Insanu. 2015. Analisa Perbandingan Propeller Kapal Selam Tipe $B$-Series dan Au-Outline Gawn Series Pada Kapal Selam MIDGET TYPE 150M Untuk Mengoptimalkan Kinerja Kapal Selam Dengan Metode CFD, Tugas Akhir, Jurusan Teknik Perkapalan, UNDIP. SEMARANG.

[2] Huda W, Rizkhal. 2011. Analisa Pengaruh Skew Angle Terhadap Performa Propeller Dengan Pendekatan CFD, Tugas Akhir, Jurusan Teknik Perkapalan ITS : Surabaya

[3] Carlton, J.2007. Marine Propellers and Propulsion, $2^{\text {nd }}$ Edition. ButterworthHeinemann

[4] Hafiz, Dian. 2011. Analisa Pengaruh Aliran Fluida Yang Ditimbulkan Oleh Gerakan Putaran Propeller Pada Kapal Ikan 
Terhadap Tekanan Propeller dengan Pendekata CFD. Semarang : UNDIP

[5] Simbolon, Herbet. 2015, Analisa Nilai Maximum Thrust Propeller B-Series dan Kaplan Series Pada kapal Tugboat Ari 400 HP dengan Variasi Diameter, Jumlah Daun, Sudut Rake Menggunakan CFD, Tugas akhir, Jurusan Teknik Perkapalan, UNDIP : Semarang.

[6] Manik, Parlindungan, 2008, Buku Ajar Propulsi Kapal, Jurusan Teknik Perkapalan, UNDIP: Semarang

[7] Paul Anderson, Jens J.Kappel, Eugen Spangenberg, 2009, Aspects of Propeller Developments for a Submarine, Department

[8] Prof Joulbert, P.N, 2004, Some Aspect of Submarine Design Part 1 Hydrodynamics, Australian Goverment: Australian

[9] Purwanto, Ajib Wahab, 2014, Analisa pengaruh variasi hullform terhadap hambatan total kapal selam dengan Metode $C F D$, Tugas Akhir, Jurusan Teknik Perkapalan, UNDIP: Semarang.

[10] Kuiper,G. 1992. The Wageningen Propeller Series.Institut fur Schiffbau Dar Universitut Hamburg.

[11] Cahyaning Ati,Wisnu, 2011, Analisa Pengaruh Variasi Sudut Rake Propeller BSeries Terhadap Distribbusi Aliran Fluida Dengan Metode CFD, Tugas Akhir, Jurusan Teknik Sistem Perkapalan, ITS: Surabaya

[12] Huda,Nurul, 2013, Analisa pengaruh Energy Saving Device pada Propeller dengan Metode CFD, Tugas Akhir, Jurusan Teknik Perkapalan, UNDIP: Semarang

[13] Mairuhu, Thomas, 2010,Pengaruh pergantian motor induk di kapal terhadap efisiensi system propulsi, Jurnal TEKNOLOGI, Jurusan Teknik Perkapalan, UNPATTI

[14] Samsu Huda, Ismail, 2011, Perancangan program pemilihan propeller jenis wegeningen B-Seried berbasis efisiensi, Tugas Akhir, jurusan Teknik Sistem Perkapalan, FTK-ITS

[15] Rakhmadi, Wasisto, 2016, Analisa Perbandingan Kort Nozzle Terhadap Gaya
Dorong Propeller Dengan Metode CFD, Tugas Akhir, Jurusan Teknik Perkapalan, UNDIP: Semarang.

[16] Abidin, Zaenal, 2015, Komparasi Desain Dan Analisa Underwater Thruster Pada Remotely Operated Vehicle (ROV) Dengan Metode CFD, Tugas Akhir, Jurusan Teknik Perkapalan, UNDIP: Semarang. 